American University Washington College of Law

Digital Commons @ American University Washington College of

Law

Articles in Law Reviews \& Other Academic Journals

Scholarship \& Research

1997

Product Differentiation Through Space and Time: Some Antitrust

Policy Issues

Jonathan Baker

Follow this and additional works at: https://digitalcommons.wcl.american.edu/facsch_lawrev

Part of the Antitrust and Trade Regulation Commons, Civil Rights and Discrimination Commons, and the Intellectual Property Law Commons 


\section{Product differentiation through space and time: some antitrust policy issues}

BY JONATHAN B. BAKER*

After a century of interpreting the Sherman Act, antitrust has learned how to do some things quite well. We understand what is wrong with naked horizontal price fixing and market division, and we have developed strong tools to deal with those problems. We can generally prevent mergers to monopoly and we are pretty good at preventing other mergers that increase market power. At least, we can do so in the kinds of industries that antitrust grew up with, in which firms make and sell substantially similar products and compete in terms of current production and prices, rather than innovation.

But antitrust has been less successful in other areas. This article explores the problems antitrust confronts when products are

* Director, Bureau of Economics, Federal Trade Commission.

AUTHOR'S NOTE: The views expressed are not necessarily those of the Federal Trade Commission or any individual Commissioner. This article expands upon remarks delivered to The Antitrust and Trade Regulation Committee of the Association of the Bar of the City of New York, February 6, 1996. The author is grateful to Timothy Bresnahan, Stephen Calkins, Steven Salop, Gary Roberts, and Michael Wise.

(-) 1997 by Federal Legal Publications, Inc. 
differentiated. It focuses on two types of differentiation in particular. The first appears most commonly in consumer products industries, in which a large number of brands are available and the products vary in physical attributes and images. Products like soft drinks and automobiles provide examples. Here the differentiation is "spatial," to use the economist's metaphor of products located at various positions in an abstract characteristics space. The second type of differentiation emphasizes that firms in these industries often introduce new products over time. There was a time, after all, when Coke and Pepsi did not sell sugar-free or caffeinefree colas, and when General Motors and Ford did not sell subcompact cars. Product innovation can be thought of as creating goods differentiated over time.

In differentiated product settings, this article explains, antitrust has had trouble isolating anticompetitive harm and devising a procompetitive remedy within the conventional rule-of-reason, market-definition paradigm. The problems appear in legal doctrine, but their roots, and their possible resolutions, rest in economic analysis. Accordingly, this article begins, in section I, with the economics of spatial product differentiation. Section II considers merger analysis in differentiated product industries, and section III examines the problems antitrust faces in identifying anticompetitive conduct arising from the development and marketing of new products.

\section{Economics of product differentiation}

Product differentiation across space is of particular interest in merger analysis. The 1992 Merger Guidelines contain a section devoted to analyzing the unilateral competitive effects of mergers when products are differentiated. ${ }^{1}$ Although spatial product differentiation appears in multiple forms, this article will focus primarily on the common situation in which producers respond to different consumer tastes by offering different sets of product

1 U.S. Dept. of Justice and Federal Trade Commission, 1992 Horizontal Merger Guidelines, § 2.21, 4 Trade Reg. Rep. (CCH) ๆ 13,104. 
attributes or projecting different product images. ${ }^{2}$ For example, the Federal Trade Commission has over the years examined mergers in the soft drink industry. ${ }^{3}$ Soft drinks are characterized by variety in flavor, packaging, and image that together produce distinct brand identities.

Differentiation itself is not unambiguously good or bad. Buyers typically benefit from the availability of a wide variety of product offerings to serve their differing preferences. Yet differentiation can also facilitate the exercise of market power. The producer of a differentiated product often enjoys a localized monopoly and may, in consequence, be able to charge a higher price than it otherwise could.

The investments firms make in differentiation, moreover, can change a market's structure in ways that might, to first appearances, lead to the suspicion that the market is not competitive. In particular, when the firms in an industry make large investments in brand reputations and their new products pipeline, the number of firms is often low and prices are often well above seller variable costs. ${ }^{4}$ Also, firms may find it possible, and profitable, to

2 Differentiation can be thought of as spatial in at least two other settings. First, buyers may care about seller reputation, so that the plain fact of a seller's identity could differentiate its products from those of other sellers. This type of differentiation can appear in the form of buyers requiring sellers to become "qualified" to sell to them. Second, shopping or transportation cost may matter, so that differentiation appears on the basis of seller or producer location.

3 See, e.g., FTC v. Coca-Cola Co., 641 F. Supp. 1128 (D.D.C. 1986) (preliminary injunction), vacated mem., 829 F.2d 191 (D.C. Cir. 1987).

4 John Sutton, Sunk Costs and Market Structure: Price CompetiTHON, ADVERTISING AND tHe EVOLUTION OF CONCENTRATION (1991); see Timothy F. Bresnahan, Sutton's Sunk Costs and Market Structure: Price Competition, Advertising, and the Evolution of Concentration, 23 RAND J. ECON. 137 (1992). Sutton emphasizes that firms have an incentive to make fixed investments in product differentiation or $R \& D$ to reduce localized competition, thereby raising price-cost margins. Moreover, when rivals must match these investments in order to keep their products 
discriminate in price or to sell different products to different segments of the market. ${ }^{5}$

Yet it is too quick to conclude that such an industry necessarily presents an antitrust problem. These features of industry structure-high concentration, high price-cost margins, and price discrimination-are also consistent with an industry setting we should reasonably call competitive because it is characterized by free entry. ${ }^{6}$ Under such circumstances, the high price-cost margins merely cover the high fixed costs of achieving differentiation, ${ }^{7}$ and the entry constraint limits the ability of firms to use price discrimination to exploit identifiable groups of customers with

attractive to buyers, industry prices may rise through operation of the "integer effect"- the increment to prices that arises on average even with free entry when a market that previously could have held, for example, $51 / 2$ firms (of at least minimum viable scale, given the fixed costs of entry) turns into one that fits only, say, $31 / 2$ firms. Cf. N. Gregory Mankiw \& Michael D. Whinston, Free Entry and Social Inefficiency, 17 RAND J. ECON. 48 (1986) (product variety combined with the integer effect will lead to less than the socially optimal number of firms, unless these forces are compensated for by sufficient incumbent accommodation of entry); but $c f$. Steven BerRy \& Joel Waldfogel, Free ENTRY and Social InefFCIENCY IN RAdio BROAdCASTING (Nat'l Bureau Econ. Res. Working Paper $5528,1996)$ (example in which inefficiently many firms enter).

5 Economic price discrimination, that is different price-cost margins on sales of the same goods to different buyers, is not necessarily the same as discrimination under the Robinson-Patman Act.

6 The technical literature generally employs the term "free entry" to mean that the economic profits of incumbent firms are driven to zero (or as close as practicable given the integer constraint). Typically, this outcome will require significant accommodation of entry by incumbents. The literature on contestable markets emphasizes that high concentration is not necessarily inconsistent with competitive outcomes in free-entry settings. See William J. Baumol et al., Contestable Markets and the THEORY OF INDUSTRY STRUCTURE (1982).

7 An incumbent's average prices will not exceed a new entrant's average variable cost by enough to induce entry. Note that what have been fixed costs for incumbents are typically variable costs for the prospective entrant. Once the new firm enters, it expects to earn a profit contribution (revenues less short-run postentry variable costs) that covers its fixed costs. 
inelastic demand. 8 On the other hand, if incumbent firms are able to commit to aggressive postentry competition, rather than accommodating entry, they can achieve prices above what competition would permit. ${ }^{9}$ Investments in product differentiation could be one way of doing so. ${ }^{10}$

This analysis suggests that ease of entry can be expected to play a critical role in preserving competition in differentiated-

8 See Severin Borenstein, Price Discrimination in Free-Entry Markets, 16 RAND J. EcoN. 380 (1985); T. Holmes, The Effects of ThirdDegree Price Discrimination in Oligopoly, 79 AM. ECON. REv. 9 (1989); Daniel F. Spulber, Regulation and Markets 544-48 (1989). With free entry, an entrant expecting to mimic the price discrimination of incumbents would most likely generate the greatest contribution margins (price less marginal cost, relative to price) from those identifiable groups of buyers with the most inelastic demand. The aggregate contribution (price less variable cost, summed over all groups of buyers) would be capped, however, by virtue of the constraint that average revenue not exceed entrant's average variable cost by enough to induce entry. (One striking implication: if demand by any one group of buyers becomes more elastic, that group will see prices fall while other buyers may pay higher prices. For example, suppose that several small employers offering employee health benefits begin to purchase coverage as a group, thereby threatening to divert a large number of patients in response to a small price rise and thus making the demand doctors face from these employers more elastic. The employers will likely be able to negotiate a lower price. If the local health care markets are characterized by free entry, one result may be slightly higher prices for other groups of patients.)

9 The greater the sunk investments required for entry, and the greater the incumbents' commitment to a rapid and aggressive response, the more entry is deterred by the threat of postentry competition. See generally Richard J. Gilbert, Mobility Barriers and the Value of Incumbency, in 1 HANDBOOK OF INDUSTRIAL ORganization 475 ( $R$. Schmalensee \& R. Willig eds., 1989); Steven C. Salop, Strategic Entry Deterrence, 69 AM. ECON. Rev. 335 (Papers and Proceedings 1979).

10 That is, firms may achieve higher prices through strategic investments in product differentiation if those investments effectively commit incumbent firms to respond more rapidly or aggressively to entry (thus changing the nature of the postentry oligopoly interaction). Gilbert, supra note 9, at 503-06; Richard Schmalensee, Entry Deterrence in the Readyto-Eat Breakfast Cereal Industry, 9 BELI J. ECON. 305 (1978). 
product markets. In contrast, interfirm rivalry may be a less significant competitive force than in homogeneous product industries, because competition is localized in differentiated-product settings. ${ }^{11}$ This point will return in the discussion of antitrust issues that arise from the introduction of new products.

\section{Mergers where spatial differentiation is extreme}

Extreme product differentiation-the situation that arises when firms sell a wide range of styles, flavors, colors and similar characteristics, so there are no "gaps" in the chain of substitutescan befuddle the antitrust analysis of mergers. ${ }^{12}$ The law is often preoccupied with defining a single "market" so that proxies for market power, usually market share, can be brought to bear on the ultimate questions. The output of this method, the impossibly gerrymandered left-handed one-eyed man with a limp product market, often appears in after-dinner speeches as comic relief. And the resulting market shares often mislead about the potential for the merger to harm competition in the localized regions in which differentiated product sellers may be able to raise price. Where products are highly differentiated, the competition policy concern is more likely to be about single-firm effects than about interfirm coordination. The gains from coordinating an increase in the prices of distant substitutes are likely to be low, compared to the gains from reducing competition among close substitutes. Thus the concern is typically less about what might happen in the outer reaches of a "market," than about what might happen among the merging firms' own products.

iI Incumbent firms may find that price cutting does not allow them to increase sales enough to compensate for the lost profit margin on their current output. (If so, a price above incumbent marginal cost may be sustainable.) Price cutting is typically a less profitable strategy the more marginal costs rise with output, the more products are differentiated, and the more rapidly rivals can respond by matching the price cut.

12 Markets with firms differentiated by location can also be highly differentiated, raising similar difficulties for merger analysis. Examples may include supermarkets, hospitals or drug stores. 
The brewing industry during the 1970 s provides an example illustrating the problems of relying on market definition and market shares to identify market power among sellers of differentiated products. ${ }^{13}$ Pabst and Coors had similar shares of the national beer "market," and each had high shares in a distinct region of the country. Although market shares did not strongly distinguish the firms, they played very different competitive roles: Coors was largely free from localized competition while Pabst was not. Moreover, the market share leader, Anheuser-Busch (the seller of Budweiser), exercised little market power after 1975. Combinations among these brewers could have made a Budweiser price increase profitable, because a combination with either brand would have removed a constraint on Anheuser-Busch's ability to raise price. But such mergers would not have led to an increase in the price of Pabst's or Coors's flagship brands, because their positions were different: the Coors brand was isolated, with no other brand constraining it, while the Pabst brand was constrained by many others. In short, market shares did not reveal the competitive role played by these firms or their ability to exercise market power.

When it comes to identifying market power in differentiatedproduct industries, as this example suggests, it may not be helpful to commence the antitrust analysis by asking, What is the relevant market? and then computing market shares. Rather, in examining the competitive effects of a transaction such as a merger, the first question should be, If one product's price rises, and its sales decline, where do the lost buyers go? ${ }^{14}$ This question is critical

13 This example is based on Jonathan B. Baker \& Timothy F. Bresnahan, The Gains for Merger or Collusion in Product-Differentiated Industries, 33 J. IND. ECoN. 427 (1985) and Jonathan B. Baker \& Timothy F. Bresnahan, Estimating the Residual Demand Curve Facing a Single Firm, 6 INT'L J. IND. ORG. 283 (1988). See also Jonathan Baker \& Timothy F. Bresnahan, Empirical Methods of Identifying and Measuring Market Power, 61 AntITRust L.J. 3 (1992).

14 Carl Shapiro asks a similar question in seeking to estimate what he calls the "diversion ratio," that is, the fraction of the sales lost by the product whose price is increased that would be captured by the other 
because it helps identify situations in which localized competition among the products of the merging firms keeps prices low-and thus helps identify the products for which the firms will have a strong incentive to raise price following the acquisition. That is, if a firm selling product $A$ acquires product $B$, its incentive to raise the price of $A$ will be greater the larger the number of buyers of $A$ who would react to a price increase by shifting to $B .{ }^{15}$ The concern in these combinations of differentiated products is what happens to prices if firms internalize what was previously important localized competition.

Consumer substitution patterns in response to a price increase are not the only factors important to the analysis of unilateral competitive effects. The merged firm's incentive to raise the price of product $A$ is also greater, for example, the higher the price-cost margin on product $B$ relative to product $A$, and the less rival firms selling other potential substitutes respond by competing more aggressively on price or modifying product characteristics to become even closer substitutes. Economists have developed a number of good techniques for integrating these factors, ${ }^{16}$ all of which have been or would be used by government enforcers in appropriate cases. ${ }^{17}$ With the development of these empirical tools, the competition of market shares is often no longer the best

party's product. Carl Shapiro, Mergers With Differentiated Products, 10 ANTTTRUST 23 (1996).

15 Of course, if producers of $A$ and $B$ combined, it would also be important to find out how buyers of $B$ would respond if its price increased. Perhaps the merged firm would have an incentive to raise $B$ 's price too, and perhaps not.

16 See generally, Jonathan B. Baker, Contemporary Empirical Merger Analysis, GeO. MASON U. L. REV. (forthcoming 1997).

17 Recent examples include the state of New York's unsuccessful challenge to the cereal industry merger and the Antitrust Division's successful challenge to some aspects of a recent bread baking merger. New York v. Kraft General Foods, Inc., Nabisco Cereal, Inc., et al., Civil No. 93-0811 (KMW) (S.D.N.Y. February 22, 1995); U.S. v. Interstate Bakeries Corp. \& Continental Baking Co., Civil Action No. 95C-4195 (N.D. Ill., complaint filed July 20, 1995). See also LAWRENCE WhITE \& JoHN 
place to start in assessing the competitive consequences of mergers in industries characterized by extreme product differentiation.

Can legal doctrine follow economic analysis by moving beyond the traditional reliance on market share proxies, to deal with the issue of market power more directly? The answer has been thought to depend on the statutory setting. The Clayton Act statutory language requires demonstration of competitive effects in a "line of commerce" and "section of the country." Even so, the Clayton Act language does not demand the use of market-share proxies for measuring competitive effects. A merger can also be challenged under the Sherman Act, in which case the rule of reason would apply, calling for balancing competitive harms and benefits. But applying the rule of reason does not necessarily entail definition of a market and proof of market shares, although often that is what happens.

The possibility of observing and measuring market power more directly suggests a new notion for Clayton Act doctrine: the res ipsa loquitur market definition. When a piano crashes onto the sidewalk, the law does not ask whether someone was negligent; instead, it goes right to the question of who. This approach could translate to antitrust. Suppose that a merger or other practice can be shown, directly, to harm competition, for example by making an increase in price likely. But suppose also that it is hard to draw lines around a market, because the array of differentiated products is broad and seamless. If competition will be harmed, some market must exist within which competition takes place. Just exactly where the market's boundaries are may not be very important, though. Nor may it matter much whether the market in which the harm occurs is large or small. All that should matter to the doctrine is that the "market" contain the products and locations that circumscribe the consumer injury.

KWOKA, The ANTITRUST ReVolution 85 n14 (1989) (referencing an empirical analysis of likely competitive effects in mergers among soft drink producers). In these cases, high-quality data about consumer responses, taken from supermarket scanners, made econometric analysis feasible. 
There is ample legal authority for dispensing with the market definition exercise in rule-of-reason cases. If the harm is shown directly, there is no point in requiring that it also be shown by proxy. ${ }^{18}$ Proof of power to maintain price above competitive levels or to harm competition by excluding efficient competitorsappealing to the legal formulations that describe market or monopoly power in Sherman Act cases-can establish the element of monopoly power directly. It would certainly suffice in a nonmerger case brought under the Sherman Act or the Federal Trade Commission Act. It ought to be possible to devise some formal adaptation so these same principles would be available in merger cases brought under section 7 of the Clayton Act-especially given that the section 7 , section 1 and section 5 analyses of mergers are widely thought to have converged. ${ }^{19}$

Establishing the concept of a res ipsa loquitur market will undoubtedly need to overcome some forensic hurdles. ${ }^{20} \mathrm{~A}$ likely complaint will be that the res ipsa market comes perilously close to the kind of ad hockery that gave "submarkets" a bad name. It need not, if the idea is applied responsibly. After all, the point of the res ipsa approach is really to bypass formal market definition. What would end up identified as the focus of competition concern might not, by conventional standards, be called "the market," but

18 FTC v. Indiana Fed'n of Dentists, 476 U.S. 447, 460-61 (1986); NCAA v. Board of Regents, 468 U.S. 85, 109-10 (1984). See Richard Schmalensee, Another Look at Market Power, 95 HARv. L. Rev. 1789, 1807 (1982); $c f$. Franklin M. Fisher, Horizontal Mergers: Triage and Treatment, 1 J. ECON. PERSPECTIVES, Fall 1987, at 30 (the "real questions" worthy of "serious analysis" involve competitive effects rather than market definition); Thomas G. Krattenmaker et al., Monopoly Power and Market Power in Antitrust Law, 76 GEORGETOWN L.J. 241 (1987) (suggests ways that the approach to market definition should vary with the competitive effect alleged).

19 Phillip AReeda \& Herbert HovenKamp, 2 Antrtrust Law $\uparrow 304$, ก 397f (rev. ed. 1995).

20 Until experience has clarified how to apply this analytic approach, it would not be appropriate to employ it in criminal cases brought under the Sherman Act. Criminal cases are exceedingly rare in merger enforcement, however. 
would be given that label as a kind of legal fiction so we can get on with the more important task of applying economic analysis to identify competition problems.

The brewing industry example can help make the argument more concrete. If the government could demonstrate directly-for example based in part on the kind of econometric evidence previously cited-that the acquisition of Pabst by Anheuser-Busch would give Anheuser-Busch the incentive and ability to raise the price of its flagship brand, Budweiser, why should it still be necessary for the government to prove whether light beer, foreign imports, beer from microbreweries, nonalcoholic beer, wine, or soft drinks are in the relevant market in order to prevail in a challenge? It is not satisfactory to answer that under such circumstances the relevant market, properly defined under the Merger Guidelines, would include only Budweiser and Pabst Blue Ribbon, making this transaction challengeable as a merger to monopoly. After all, it is difficult to imagine a judge, employing the received approach of defining the market before reviewing the competitive effects evidence and fearful of criticism for gerrymandering, defining a market that includes Budweiser but not Miller. $^{21}$

The legal problem, like the economic problem, is not one of conception but of proof. Within a market, differentiation can lead to localized competition problems that depend little on the precise location of the market's boundaries. Those problems may be demonstrated by quantitative economic evidence about the extent of market power exercised, though the data needed for this kind of analysis can be hard to come by and even if data are available, quantitative evidence may not strongly reveal or rule out the potential for competitive problems. Proof of particular, localized effects may also rely on other evidence. This other evidence may include the parties' admissions in their planning and marketing

21 Also, more technically, if the Budweiser price would not quite rise $5 \%$, the Guidelines would require broadening the product market in any case. 


\section{8 : The antitrust bulletin}

documents that identify their principal competitors or claim credit for their plans' anticipated exclusionary or price elevation effects. It may also include the testimony of customers or rivals. This is the same kind of evidence that is typically adduced in defining relevant markets. That is no accident, for competitive effects analysis is concerned about identifying the products that constrain the exercise of market power by the merging firms, just as the familiar market definition exercise is also concerned. ${ }^{22}$ In an industry with extreme product differentiation, though, the output of the standard market definition exercise can be unnecessary and distracting.

It is useful to anticipate and address some possible concerns about the res ipsa approach to market definition in the kind of markets where it would work best-those with few gaps in the chain of substitutes, so that any market definition would appear arbitrary. First, this approach does not turn the unilateral theory of anticompetitive effects for differentiated products, set forth in the 1992 Merger Guidelines, into a per se theory of liability. On weighing the evidence, a court might discover that significant competition is not internalized by the merger of the seller of brand $A$ and the seller of brand $B$-much as the econometric evidence discussed above suggested that a Coors-Pabst merger would not have harmed competition during the 1970s. Moreover, the merger will not have anticompetitive effects if it induces timely, likely and sufficient repositioning of rivals' products or entry. The brewing industry demonstrates that repositioning and entry possibilities cannot be ignored, even when they would require substantial sunk investments in brand reputation: Miller's marketing investments in the early 1970 s, repositioning its flagship brand through the "Miller Time" advertising campaign and introducing Miller Lite, appear to have competed away Bud-

22 For example, just as a narrow product market definition can be challenged by showing that buyers might substitute to products outside the market, a claim about buyer substitution patterns can be questioned by showing the importance of considering a broader set of alternatives. 
weiser's previous market power. ${ }^{23}$ Also, efficiencies matter. For example, if the merger lowers the marginal costs of producing and selling brands $A$ or $B$, prices could fall on net even if some localized competition is removed.

Second, the enforcement agencies must engage in market definition, as the basis for computing market shares and HerfindahlHirschman indexes (HHIs), in order to determine whether a transaction falls into the Merger Guidelines' safe harbors. ${ }^{24}$ It is worth noting, however, that when evaluating mergers among sellers of differentiated products, market share measures may not help achieve two important purposes of a safe harbor. ${ }^{25}$ One purpose is to remove from review transactions where the potential for the exercise of market power is limited. Yet market shares are often poor predictors of market power in settings where product differentiation is extreme, and thus may not reliably serve that purpose. Another purpose is to implement a presumption about efficiencies, and here again market share measures may serve the purpose poorly. High market shares for brands of differentiated products may well be correlated with better products or lower costs. But to the extent brand capital is less transferable to other

23 See Baker \& Bresnahan, The Gains for Merger or Collusion in Product-Differentiated Industries, supra note 13.

24 In addition to the familiar safe harbors involving the HHI, the unilateral competitive effects sections of the 1992 Guidelines also make reference to safe harbors that apply when the merging firms in aggregate account for less than $35 \%$ of the market. With respect to firms distinguished primarily by differentiated products, however, the language employed in the Guidelines appears to apply the $35 \%$ safe harbor only when market shares are employed as a benchmark for measuring likely competitive effects ( $\$ 2.2)$, and not when other data are used to make that determination. Some agency officials have nevertheless described the $35 \%$ safe harbor as applying regardless of how the degree of competition among products is estimated. See, e.g., interview with Assistant Attorney General James Rill, 61 ANTITRust L.J. 229, 238 (1992); Paul Denis, Practical Approaches: An Insider's Look at the New Horizontal Merger Guidelines, ANTITRUST, Summer 1992, at 9.

25 The problems noted below are less acute when products are relatively homogeneous. 
uses than physical capital, combinations among sellers of branded products may on average generate less scope for efficiencies than would mergers among sellers of homogeneous goods. Until better ways are developed to implement the reasonable presumption that mergers generate some efficiencies in the differentiated products case, however, the enforcement agencies can be expected to continue to rely upon the safe harbors built into the Merger Guidelines to inform their exercise of prosecutorial discretion.

In summary, antitrust's confusion about extremely differentiated products in merger analysis comes because market definition can be difficult and uninformative in such industries. That confusion can be reduced by the use of economic tools to identify harm directly, rather than relying on the proxy of market share. Doing so will help courts balance better the unquestioned but hard-tomeasure value of variety and choice against what society is willing to pay for that variety in localized market power.

\section{Can investment in new products harm competition?}

Buyers can benefit from the new products that result from innovation, ${ }^{26}$ an activity that can be thought of as product differentiation over time. And while the results of research and development may be unpredictable, firms can influence the types of new products they produce and the probability of R\&D success through the extent and direction of their $R \& D$ and new product marketing expenditures.

Seller investments in developing and marketing new products benefit buyers by improving product quality, widening product variety, and expanding buyer choice. But when it is an already leading firm that engages in aggressive innovation, in a market that is already highly concentrated, antitrust sensitivities can be aroused. Does the R\&D and marketing investment represent

26 Although this discussion focuses on new products, it is important to recognize that innovation may also benefit buyers by allowing firms to improve the quality of existing products or to lower their production costs. 
competition "on the merits," the creation of new and better products that benefit consumers? Or does it merely amount to a strategy of discomfiting and discouraging competitive threats from fringe firm innovations, harming competition and consumers?

An illustration familiar to antitrust practitioners is presented by the Berkey-Kodak litigation of the 1970s. ${ }^{27}$ That case explored the obligations an innovating monopolist might have toward its fringe firm competitors. Other antitrust cases that have wrestled with leading firm innovation include the FTC's Xerox case in the mid-1970s, ${ }^{28}$ which ordered compulsory licensing of xerography technology, and more recently the Justice Department's Microsoft case, ${ }^{29}$ which imposed some limits on the kinds of contracts Microsoft can enter. The succession of technologies and products in these industries-photography, xerography, and software-suggests a now seemingly familiar pattern. The leading firm introduces successive waves of new products or technological systems. ${ }^{30}$ These products may be improvements on previous ones or replacements for them. They may be incompatible with the previous versions or with those of the fringe firms, thus making old or competing products obsolete. Fringe firms may be reduced to reacting to the leading firm's strategy. ${ }^{31}$

27 Berkey Photo, Inc. v. Eastman Kodak Co., 603 F.2d 263 (2d Cir. 1979).

28 In re Xerox Corp., 86 F.T.C. 364 (1975). See Timothy F. Bresnahan, Post-Entry Competition in the Plain-Paper Copier Market, 75 AM. Econ. Rev. 15 (Papers \& Proceedings 1985).

29 U.S. v. Microsoft Corp., 1995-2 Trade Cas. (CCH) $₫ 71,096$ (D.D.C. 1995) (consent decree).

30 For a discussion of how one leading firm manages its product portfolio to keep successive waves of technology coming to market, see Michael A. Cusumano \& Richard W. Selby, Microsoft Secrets (1995).

31 Yet leading firms need not be aggressive innovators. They may instead accommodate fringe innovations and investment. That is what the Big 3 automakers did in the 1960s and 1970s in response to product and process innovations from Europe and Japan. Jonathan B. Baker, Fringe Firms and Incentives to Innovate, 63 ANTTRUST L.J. 621 (1995). The rea- 
Courts and enforcers must proceed with caution in applying the antitrust laws in this area. On the one hand, leading firms aggressively innovating can, in principle, harm competition. Because ease of entry plays a critical role in preserving competition in many differentiated-product markets, it is appropriate to worry that research and development investments could be an instrument of strategic entry deterrence. On the other hand, it is sensible to be wary of drawing that conclusion, because investments in innovation often have payoffs in better products, lower costs, or higher quality. No one wants to kill the goose that may be laying golden eggs-even if we fear the goose may be eating its rivals' young.

Antitrust's fundamental task here is finding ways to challenge those $R \& D$ and marketing strategies involving new products that deter competition by rivals without producing benefits to buyers, and it is a tough assignment. ${ }^{32}$ One reason it is difficult is that firms will often not know how their R\&D efforts will work out.

sons leading firms might accommodate rather than retaliate include fear that new products might cannibalize their other product investments and a belief that the fringe firm threat will be confined and will not spread. See id. at 637-39. If leading firms are not aggressive, they are unlikely to get into antitrust trouble for suppressing innovation. Of course, they may still get into other kinds of antitrust trouble, for example, by fixing prices.

32 The difficulty of doing so is often exacerbated when the investment in research and development does not merely lead to new products, but also sets an industry standard. Then competition may involve rivalry over the opportunity to create the next standard even more than rivalry among the products within a standard. A standard-setter with intellectual property protection might deter competition or control access to the industry, thus inhibiting existing rivals employing the existing standard as well as potential rivals with a potentially better one. On the other hand, standards often also amplify the consumer benefits from innovation, and intellectual property protection may be necessary to induce firms to invest in developing and promoting potential standards. And if, as often happens, adopting the standard facilitates the growth of network externalities, the stakes are raised even higher, for the scope of the potential harm to competition and the range of the potential efficiency benefits are likely both further increased. 
Thus, both the buyer benefits and the rival deterrent effects of $\mathrm{R} \& \mathrm{D}$ must be assessed from an ex ante perspective, focusing on what would be reasonable to expect at the time of innovation-a question related to, but not identical with, asking whether the R\&D actually benefited buyers or harmed competitors. The likely approach to this task was suggested by the Berkey panel, which explained that Kodak's introduction of a new film format and simultaneous withdrawal of an old format, forcing photographers to buy photofinishing from Kodak rather than Berkey, could have supplied the "bad act" necessary to support a charge of monopolization-if the new format had not been better or cheaper than the old. ${ }^{33}$

Despite the difficulty of the task, antitrust has, on the whole, responsibly undertaken the assignment of distinguishing procompetitive innovation from monopolizing exclusion. Indeed, it would be difficult to sustain the charge that antitrust routinely penalizes success. For example, the government ultimately withdrew its monopolization case against IBM, and virtually all of Berkey's private monopolization verdict against Kodak was reversed on appeal. ${ }^{34}$ Similarly, the antitrust standards applied by the courts tend to resolve unclear cases in favor of the innovative leading firms. The courts have admittedly signaled a willingness to target spurious new product investments-that is, research and development or new product marketing expenditures by leading firms-that appear purely, or even largely, aimed at restricting competition by preempting rivals, without giving consumers much

33 Berkey Photo, 603 F.2d at 287 n.39. The court also concluded that Berkey might have recovered for Kodak's refusal to package its new film for camera formats other than the ones Kodak already made, if Berkey had shown it suffered damages as a result. Id. at 290 . The judgment on that count was reversed because Berkey presented no evidence that it was injured in this way. The court also held that the leading firm's conspiracy with others to prevent disclosure of its innovation could be actionable, but as a violation of section 1, not section 2, of the Sherman Act. Id. at 302.

34 Admittedly, reaching these results can cost time and money. 
benefit. ${ }^{35}$ This approach is consistent with the Berkey decision's treatment of dominant firm innovation. ${ }^{36}$ But courts hesitate to find that new product $R \& D$ or marketing activities create antitrust liability when defendants proffer a legitimate business justification. In particular, courts are reluctant to find that a firm misused its monopoly power through the introduction of any innovation that lowers cost, improves quality or performance, or is otherwise desirable to consumers, even if the innovation creates incompatibilities or otherwise raises costs to rivals. ${ }^{37}$ And while the essential facilities and monopoly leveraging doctrines could help plaintiffs challenging leading firm practices, the courts may now be limiting their application. ${ }^{38}$

35 The possibility of nonprice predation through the development and marketing of new products is well established in the economics literature. Janusz A. Ordover \& Robert D. Willig, An Economic Definition of Predatory Product Innovation, 91 Y ALE L.J. 8, 22-52 (1981); Joseph Farrell \& Garth Saloner, Installed Base and Compatibility: Innovation, Pre-Announcements and Predation, 76 AM. ECON. REv. 940 (1986); Janusz A. Ordover \& Garth Saloner, Predation, Monopolization, and Antitrust, in 1 HANDBOOK OF INDUSTRIAL ORGANIZATION 537, 563 (Richard Schmalensee \& Robert D. Willig eds., 1989); see generally Thomas Krattenmaker \& Steven Salop, Anticompetitive Exclusion: Raising Rivals' Costs to Achieve Power Over Price, 96 Yale L.J. 209 (1986).

36 See Berkey Photo, Inc. v. Eastman Kodak Co., 603 F.2d 263 (2d Cir. 1979); In re IBM Peripheral EDP Devices Antitrust Litig., 481 F. Supp. 965, 1002-03 (N.D. Cal. 1979), aff'd sub nom., Transamerica Computer Co. v. IBM, 698 F.2d 1377, 1383 (9th Cir.), cert. denied, 464 U.S. 955 (1983); Litton Sys. v. AT\&T, 700 F.2d 785 (2d Cir. 1983), cert. denied, 464 U.S. 1073 (1984).

37 Berkey Photo, Inc. v. Eastman Kodak Co., 603 F.2d 263 (2d Cir. 1979); Northeastern Tel. Co. v. AT\&T, 651 F.2d 76, 93 (2d Cir. 1981); California Computer Prods., Inc. v. IBM, 613 F.2d 727, 744 (9th Cir. 1979).

38 Compare Phillip Areeda, Essential Facilities: An Epithet in Need of Limiting Principles, 58 ANTTTRust L.J. 841 (1990) (emphasizing potential breadth) with William Kovacic, Antitrust Analysis of Joint Ventures and Teaming Arrangements Involving Government Contractors, 58 ANTITRUST L.J. 1059, 1104 n.242 (1990) (recent narrowing). Compare Berkey Photo, 603 F.2d at 276 (monopoly leveraging can be demon- 
These doctrinal developments will likely channel some future litigation over the alleged exclusionary practices of innovative leading firms into disputes about alternatives. As the late Professor Areeda put it, an anticompetitive restraint can be redeemed only if it is reasonably necessary to a legitimate objective; and to be reasonably necessary, the restraint must promote that objective "significantly better than the available less restrictive alternatives." 39 Areeda goes on to ask, "Can that objective be achieved as well without restraining competition so much?"40 That question could appear directly if the litigation arises under Sherman Act section 1 and the rule of reason applies, ${ }^{41}$ or indirectly through the determination of whether a monopolist has engaged in a "bad act" sufficient to support a Sherman Act section 2 claim.

In sum, firm investments in the development and marketing of new products-differentiation over time-can harm competition notwithstanding the fact that new products are introduced. The more the investments appear aimed at creating aggressive postentry competition rather than providing buyers with valuable new consumption alternatives, the easier it is to conclude that they are methods of weakening or removing the constraint on pricing imposed by the threat of entry. But the stakes are high in

strated if a monopolist merely obtains a competitive advantage in a second market, without attempting to monopolize it) with Alaska Airlines v. U.S., 948 F.2d 536 (9th Cir. 1991) (leveraging charge requires threatened or actual monopoly in second market) and Fineman v. Armstrong World Industries, 1992 Trade Cas. (CCH) \ 70,010 (3d Cir. 1992) (same).

39 Phillip E. Areeda, 7 Antitrust Law $\uparrow 1505$ (1986); $c f$. U.S. Department of Justice and Federal Trade Commission, Antitrust Guidelines for the Licensing of Intellectual Property, $\S 4.2$ (1995). "Less restrictive alternative" analysis examines alternatives reasonably available at the time the restraint was imposed, thus comparing alternatives from an ex ante perspective. ERNEST GellHorN \& William E. Kovacic, ANTITRUST LAW \& ECONOMICS IN A NuTSHELl 259 (1994).

40 Phillip E. Areeda, 7 Antitrust Law 91505 (1986).

41 The alleged exclusionary practice could involve an agreement between the leading firm and a supplier, for example, thus permitting a section 1 charge. 
distinguishing such competitively malignant investments from welfare-enhancing $R \& D$ and new product marketing expenditures, because the costs of error can be large when dealing with innovation. ${ }^{42}$ In consequence, we must proceed with caution and care in applying the antitrust laws in this area, especially when the R\&D or new product marketing investments at issue produce demonstrable benefits to consumers.

\section{Concluding comment}

Product differentiation-over space and across time-presents special challenges for antitrust law. Cases in differentiated-product industries often involve difficult analytic tasks, novel fact patterns, and high stakes. Yet, through the application of economic analysis, antitrust is increasingly able to discriminate between anticompetitive and procompetitive conduct in these settings.

42 Challenges to new product development and marketing efforts as instruments of entry deterrence will likely be the most difficult in an oligopoly setting, where none of the leading firms is a section 2 monopolist and the firms may adopt entry- and innovation-deterring practices without entering into a demonstrable Sherman Act section 1 agreement. This situation seems appropriate for the application of section 5 of the Federal Trade Commission Act, either through enforcement actions or some form of competition rulemaking, to clarify what kinds of strategic "investments" in deterring competition are to be discouraged. $C f$. Jonathan Baker, Two Sherman Act Section I Dilemmas: Parallel Pricing, the Oligopoly Problem, and Contemporary Economic Theory, 38 ANTITRUSt Bull. 143, 207-19 (1993). 